\title{
ACINETOBACTER AND SIMILAR ORGANISMS IN EAR INFECTIONS
}

\author{
J. V. DADSWELL* \\ Department of Pathology and Bacteriology, Institute of Laryngology and Otology, London WCI
}

SYSTEMIC human infections caused by organisms of the acinetobacter group, or "oxidase-negative moraxellas" as they are sometimes called, have been reported with increasing frequency since De Bord (1939) first drew attention to their medical significance as organisms capable of confusing the diagnosis of gonorrhoea by the smear method. Although subsequently described under such generic names as Mima, Herellea, Neisseria, Bacterium, Achromobacter and Moraxella, there now seems general agreement that they belong to the genus Acinetobacter (Cowan and Steel, 1974). Organisms of this group have also been isolated from infected ears (Brooke, 1951; Scott and Mahoney, 1953; Lutz et al., 1956; De Torregrosa and Ortiz, 1961; Reynolds and Cluff, 1963; Brodie and Henderson, 1964; Shmilowiz, Avissar and Ephrati, 1968; Wright, 1970), but few attempts seem to have been made to determine their pathogenicity in this site.

The present paper reports the isolation of Acinetobacter strains from ear swabs and mastoid bone chips obtained from patients with acute or chronic otitis media, or otitis externa, and clinical details are given in an attempt to discover the pathogenicity of these organisms in this situation. An estimate is also made of the prevalence of Acinetobacter in normal ears.

\section{MATERIALS AND METHODS}

Most of the strains were isolated from clinical material obtained from patients attending the Royal National Throat, Nose and Ear Hospital, London. To ascertain the prevalence in normal ears, swabs were taken from the external auditory canals of volunteer students and staff, with no history of ear disease, at King's College Hospital Medical School, London.

Two type strains of Acinetobacter anitratus (NCTC nos. 7844 and 8102) and one of Acinetobacter lwoffi (no. NCTC5866) were obtained from the National Collection of Type Cultures. Two further type strains of $A$. anitratus and three of $A$. lwoffi were kindly provided by Dr A. Henderson of the Royal Maternity Hospital, Glasgow. All type strains were examined in parallel with the clinical isolates.

Identification of the clinical isolates was made in the first instance by their characteristic colonial appearance, after overnight aerobic incubation on MacConkey's agar at $37^{\circ} \mathrm{C}$; their non-lactose-fermenting colonies were composed of non-motile gram-negative cocci or cocco-bacilli and bacilli. Confirmatory identification was made by standard diagnostic methods (Cowan and Steel, 1974), except that capsules were stained by the Prussian blue method of Berenbaum (1955), nitrate reduction was determined by the method of Cook (1950), and soap tolerance by means of a soap-agar plate (Billing, 1955). Sugar-fermentation reactions were tested with cultures in peptone water containing $1 \%$ of the test sugar.

Received 5 Jan. 1976; accepted 19 Jan. 1976.

* Present address: Public Health Laboratory, Royal Berkshire Hospital, Reading RG1 5AN.

J. MED. MICROBIOL.-VOL. 9 (1976) 
TABLE I

Number of strains of each main biotype showing the indicated properties

\begin{tabular}{|c|c|c|c|c|c|c|c|c|}
\hline \multirow{2}{*}{\multicolumn{3}{|c|}{$\begin{array}{l}\text { Total number of examples of } \\
\text { each main biotype examined }\end{array}$}} & \multicolumn{6}{|c|}{ Number of strains showing } \\
\hline & & & $\begin{array}{l}\text { capsular } \\
\text { staining }\end{array}$ & $\begin{array}{l}\text { urease } \\
\text { activity }\end{array}$ & $\begin{array}{c}\text { citrate } \\
\text { utilisation }\end{array}$ & $\begin{array}{l}\text { lecithinase } \\
\text { activity }\end{array}$ & $\begin{array}{l}\text { gelatin } \\
\text { liquefaction }\end{array}$ & $\begin{array}{l}\text { soap } \\
\text { tolerance }\end{array}$ \\
\hline \multirow{2}{*}{$\begin{array}{c}\text { Acinetobacter } \\
\text { anitratus }\end{array}$} & 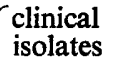 & 32 & 2 & 6 & 30 & 6 & 16 & 10 \\
\hline & $\begin{array}{l}\text { type } \\
\text { strains }\end{array}$ & 4 & 0 & 4 & 3 & 1 & 1 & 0 \\
\hline \multirow{2}{*}{$\begin{array}{l}\text { Acinetobacter } \\
\text { lwoffi }\end{array}$} & 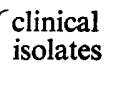 & 22 & 4 & 6 & 16 & $3(1 \mathrm{NT})$ & 13 & $7(1 \mathrm{NT})$ \\
\hline & $\begin{array}{l}\text { type } \\
\text { strains }\end{array}$ & 4 & 1 & 4 & 1 & 0 & 1 & 0 \\
\hline \multicolumn{2}{|l|}{ Moraxella } & 3 & 0 & 1 & 2 & 0 & 0 & 0 \\
\hline \multicolumn{2}{|l|}{ Achromobacter } & 1 & $\mathbf{0}$ & 0 & 1 & 0 & 1 & 0 \\
\hline
\end{tabular}

$\mathrm{NT}=$ not tested.

The antigenic relationships of these strains were investigated by means of agglutination reactions with nine different antisera raised against strains of $A$. lwoffii isolated at the City Hospital, Aberdeen, (Brodie and Henderson, 1964) and kindly supplied by Drs J. Brodie and A. Henderson.

Antibiotic sensitivities were determined by means of the comparative (disk) method on blood-agar plates, with Escherichia coli as a control organism.

The pathogenicity for mice was determined by inoculating $0.2 \mathrm{ml}$ of an overnight nutrient (digest) broth culture of each strain into the peritoneal cavity of each of two mice. The mice were then observed daily and any survivors were killed after 7 days. All the mice were examined post mortem, when cultures were taken from the peritoneum.

The clinical details of the patients from whom the organisms were isolated were studied, with particular reference to the duration of the illness, severity of symptoms, and the nature of any antibacterial therapy.

\section{ReSULTS \\ Origins of clinical strains}

Fifty-seven strains were isolated from patients with ear infections and one strain was isolated from swabs taken from 50 normal ears.

\section{Properties of strains}

All clinical strains were gram-negative cocci, cocco-bacilli or bacilli and gave positive reactions for catalase and negative reactions for $\mathrm{H}_{2} \mathrm{~S}$ and indole production. Most strains were non-motile, nitratase negative, oxidase negative, and gave negative methyl-red (MR) and Voges-Proskauer (VP) reactions; but one strain was motile, one was nitratase positive, three were oxidase positive and three gave positive reactions in one or both of the VP and MR tests. 
TABLE II

Agglutination titres obtained with 23 clinical isolates of acinetobacter-like organisms and eight type strains of Acinetobacter in tests with antisera raised against nine strains of $A$. lwoffii

\begin{tabular}{|c|c|c|c|c|c|c|c|c|c|c|c|}
\hline \multirow{2}{*}{ Strain number } & \multirow{2}{*}{ Biotype } & \multicolumn{9}{|c|}{ Titre of antiserum no. } & \multirow{2}{*}{$\begin{array}{c}\text { Agglutination } \\
\text { pattern }\end{array}$} \\
\hline & & 199465 & 18520 & D8460 & 19677 & D9682 & D16870 & 18516 & 17750 & 19738 & \\
\hline $\begin{array}{l}207 \mathrm{P} \\
301 \\
766 \mathrm{P} \\
827 \\
909 \\
2161 \\
2411 \\
2598 \\
2716 \\
2991 \mathrm{P} \\
3183 \\
3726 \\
3752 \mathrm{P} \\
3834 \\
3882 \\
3916 \mathrm{P} \\
3991 \\
4261 \\
4262 \mathrm{P} \\
4727 \\
4742 \\
5107 \\
5563 \\
\text { NCTC 5866 } \\
\text { NCTC } 7844 \mathrm{P} \\
\text { NCTC } 8102 \mathrm{P} \\
\text { A. anitratus } 1 \mathrm{P} \\
\text { A. anitratus } 2 \\
\text { A. lwoffii } 1 \\
\text { A. lwoffi } 2 \\
\text { A. Iwoffi } 3\end{array}$ & $\begin{array}{l}\text { A } \\
\mathbf{L} \\
\mathbf{A} \\
\mathbf{A} \\
\mathbf{L} \\
\mathbf{A} \\
\mathbf{L} \\
\mathbf{A} \\
\mathbf{L} \\
\mathbf{A} \\
\mathbf{L} \\
\mathbf{L} \\
\mathbf{A} \\
\mathbf{A} \\
\mathbf{A c h} \\
\mathbf{A} \\
\mathbf{L} \\
\mathbf{A} \\
\mathbf{A} \\
\mathbf{L} \\
\mathbf{L} \\
\mathbf{A} \\
\mathbf{A} \\
\mathbf{L} \\
\mathbf{A} \\
\mathbf{A}\end{array}$ & $\begin{array}{r}0 \\
4 \\
4 \\
32 \\
512 \\
4 \\
0 \\
0 \\
4 \\
0 \\
4 \\
0 \\
4 \\
0 \\
0 \\
32 \\
0 \\
4 \\
0 \\
4 \\
0 \\
1024 \\
4 \\
2048 \\
32 \\
4 \\
128 \\
4 \\
32 \\
4 \\
4\end{array}$ & $\begin{array}{r}0 \\
512 \\
512 \\
1024 \\
64 \\
4 \\
0 \\
256 \\
64 \\
0 \\
256 \\
0 \\
256 \\
0 \\
0 \\
128 \\
0 \\
128 \\
128 \\
64 \\
0 \\
0 \\
1024 \\
0 \\
64 \\
0 \\
0 \\
64 \\
512 \\
1024 \\
0\end{array}$ & $\begin{array}{r}0 \\
4 \\
4 \\
2048 \\
4 \\
0 \\
0 \\
2048 \\
512 \\
0 \\
2048 \\
0 \\
2048 \\
0 \\
0 \\
4 \\
0 \\
256 \\
512 \\
2048 \\
0 \\
1024 \\
4 \\
512 \\
0 \\
0 \\
0 \\
0 \\
0 \\
0 \\
0\end{array}$ & $\begin{array}{r}0 \\
0 \\
4 \\
0 \\
512 \\
0 \\
0 \\
0 \\
0 \\
512 \\
0 \\
0 \\
0 \\
0 \\
4 \\
0 \\
0 \\
0 \\
0 \\
0 \\
4 \\
0 \\
4 \\
2048 \\
4 \\
4 \\
256 \\
0 \\
0 \\
4 \\
0\end{array}$ & $\begin{array}{r}0 \\
4 \\
32 \\
4 \\
32 \\
0 \\
0 \\
4 \\
4 \\
0 \\
4 \\
0 \\
16 \\
0 \\
4 \\
16 \\
0 \\
4 \\
4 \\
4 \\
32 \\
32 \\
4 \\
2048 \\
4 \\
0 \\
0 \\
0 \\
4 \\
256 \\
0 \\
0\end{array}$ & $\begin{array}{r}0 \\
0 \\
0 \\
0 \\
256 \\
4 \\
0 \\
0 \\
0 \\
0 \\
4 \\
0 \\
0 \\
0 \\
0 \\
4 \\
0 \\
0 \\
0 \\
0 \\
0 \\
4 \\
0 \\
4 \\
4 \\
0 \\
64 \\
0 \\
0 \\
4 \\
0\end{array}$ & $\begin{array}{r}0 \\
0 \\
64 \\
128 \\
1024 \\
0 \\
0 \\
4 \\
4 \\
0 \\
64 \\
0 \\
32 \\
0 \\
0 \\
0 \\
0 \\
4 \\
4 \\
64 \\
512 \\
64 \\
4 \\
2048 \\
128 \\
256 \\
64 \\
4 \\
2048 \\
64 \\
0\end{array}$ & $\begin{array}{r}0 \\
0 \\
4 \\
0 \\
256 \\
0 \\
0 \\
0 \\
0 \\
0 \\
0 \\
0 \\
0 \\
0 \\
0 \\
4 \\
0 \\
0 \\
0 \\
0 \\
32 \\
0 \\
4 \\
2048 \\
4 \\
64 \\
4 \\
0 \\
2048 \\
0 \\
0\end{array}$ & $\begin{array}{r}0 \\
4 \\
4 \\
4 \\
2048 \\
4 \\
0 \\
0 \\
0 \\
0 \\
4 \\
0 \\
4 \\
0 \\
0 \\
32 \\
0 \\
0 \\
0 \\
0 \\
4 \\
4 \\
32 \\
2048 \\
256 \\
512 \\
0 \\
0 \\
0 \\
4 \\
0\end{array}$ & $\begin{array}{l}\dddot{\mathbf{I V}} \\
\ldots \\
\mathbf{I} \\
\ldots \\
\ldots \\
\ldots \\
\mathbf{I I} \\
\mathbf{I I} \\
\ldots \\
\mathbf{I} \\
\ldots \\
\mathbf{I} \\
\ldots \\
\dddot{\mathbf{I I I}} \\
\dddot{\mathbf{I}} \\
\mathbf{I I} \\
\mathbf{I} \\
\ldots \\
\dddot{\mathbf{I I I}} \\
\ldots \\
\ldots \\
\ldots \\
\dddot{\mathbf{I}} \\
\ldots \\
\ldots \\
\ldots \\
\end{array}$ \\
\hline
\end{tabular}

$\mathrm{A}=$ A. anitratus, $\mathrm{L}=$ A. Iwoffi, $\mathrm{Ach}=$ Achromobacter, $\mathrm{P}=$ pathogenic for mice.

Thirty-two strains produced acid in fermentation tests with glucose, galactose, $l$-arabinose, xylose and sometimes mannose, and 26 did not. The former strains could be thus identified as $A$. anitratus; 22 of the 26 non-saccharolytic strains were identified as $A$. Iwoffii, the three oxidase-positive strains as Moraxella spp. and the one motile strain as Achromobacter.

There was considerable variation among the strains in capsular staining, urease and lecithinase activity, citrate utilisation, gelatin liquefaction and soap tolerance (table I).

\section{Serological findings}

These are detailed in table II. Four broad patterns of agglutination could be distinguished, but there was little demonstrable relationship between the type strains and the clinical strains, nor between any particular serological group and pathogenicity for mice.

\section{Antibiotic sensitivities}

All of the biochemically typical clinical strains were resistant to penicillin. One type strain of $A$. lwoffi $i$ was penicillin sensitive, and all three oxidasepositive clinical isolates were also sensitive to penicillin. The one nitratasepositive strain and the one motile strain were penicillin resistant. All strains 
TABLE III

Results of antibiotic-disk-sensitivity tests

\begin{tabular}{|c|c|c|c|c|c|c|c|c|c|c|c|c|}
\hline \multirow{4}{*}{$\begin{array}{c}\text { Antibiotic } \\
\text { (content per disk) }\end{array}$} & \multicolumn{12}{|c|}{$\begin{array}{c}\text { Total number of strains of each category examined and the number showing sensitivity (S) } \\
\text { or resistance }(R)\end{array}$} \\
\hline & \multicolumn{4}{|c|}{ A. anitratus } & \multicolumn{4}{|c|}{ A. Iwoffii } & \multirow{2}{*}{\multicolumn{2}{|c|}{$\begin{array}{c}\text { Moraxella } \\
3 \text { strains }\end{array}$}} & \multirow{2}{*}{\multicolumn{2}{|c|}{$\begin{array}{l}\text { Achromo- } \\
\text { bacter } \\
1 \text { strain }\end{array}$}} \\
\hline & \multicolumn{2}{|c|}{32 clinical isolates } & \multicolumn{2}{|c|}{4 type strains } & \multicolumn{2}{|c|}{22 clinical isolates } & \multicolumn{2}{|c|}{4 type strains } & & & & \\
\hline & $\mathbf{S}$ & $\mathbf{R}$ & $\mathbf{S}$ & $\mathbf{R}$ & $\mathbf{S}$ & $\mathbf{R}$ & $\mathbf{S}$ & $\mathbf{R}$ & $\mathrm{S}$ & $\mathbf{R}$ & $\mathbf{S}$ & $\mathbf{R}$ \\
\hline $\begin{array}{l}\text { Penicillin (1.5 units) } \\
\text { Streptomycin }(10 \mu \mathrm{g}) \\
\text { Tetracycline }(10 \mu \mathrm{g}) \\
\text { Chloramphenicol } \\
\quad(10 \mu \mathrm{g})\end{array}$ & $\begin{array}{r}0 \\
30 \\
27 \\
1\end{array}$ & $\begin{array}{r}32 \\
2 \\
5 \\
31\end{array}$ & $\begin{array}{l}0 \\
3 \\
4 \\
2\end{array}$ & $\begin{array}{l}4 \\
1 \\
0 \\
2\end{array}$ & $\begin{array}{r}0 \\
17 \\
20 \\
9\end{array}$ & $\begin{array}{r}22 \\
5 \\
2 \\
13\end{array}$ & $\begin{array}{l}1 \\
4 \\
4 \\
4\end{array}$ & $\begin{array}{l}3 \\
0 \\
0 \\
0\end{array}$ & $\begin{array}{l}3 \\
3 \\
3 \\
3\end{array}$ & $\begin{array}{l}0 \\
0 \\
0 \\
0\end{array}$ & $\begin{array}{l}0 \\
1 \\
0 \\
1\end{array}$ & $\begin{array}{l}1 \\
0 \\
1 \\
0\end{array}$ \\
\hline $\begin{array}{l}\text { Erythromycin }(10 \mu \mathrm{g}) \\
\text { Novobiocin }(5 \mu \mathrm{g}) \\
\text { Neomycin }(30 \mu \mathrm{g}) \\
\text { Polymyxin } \mathrm{B}(100 \mathrm{units}) \\
\text { Ampicillin }(25 \mu \mathrm{g})\end{array}$ & $\begin{array}{r}27 \\
0 \\
32 \\
32 \\
27\end{array}$ & $\begin{array}{r}5 \\
32 \\
0 \\
0 \\
5\end{array}$ & $\begin{array}{l}4 \\
0 \\
4 \\
4 \\
1\end{array}$ & $\begin{array}{l}0 \\
4 \\
0 \\
0 \\
3\end{array}$ & $\begin{array}{l}21 \\
1 \\
22 \\
22 \\
19\end{array}$ & $\begin{array}{r}1 \\
21 \\
0 \\
0 \\
3\end{array}$ & $\begin{array}{l}4 \\
1 \\
4 \\
4 \\
4\end{array}$ & $\begin{array}{l}0 \\
3 \\
0 \\
0 \\
0\end{array}$ & $\begin{array}{l}3 \\
0 \\
3 \\
3 \\
3\end{array}$ & $\begin{array}{l}0 \\
3 \\
0 \\
0 \\
0\end{array}$ & $\begin{array}{l}\mathbf{1} \\
\mathbf{0} \\
0 \\
\mathbf{1} \\
\mathbf{0}\end{array}$ & $\begin{array}{l}0 \\
1 \\
1 \\
0 \\
1\end{array}$ \\
\hline
\end{tabular}

were sensitive to polymyxin B. Details of the other sensitivity patterns are given in table III. There was no essential difference between the sensitivity patterns of the saccharolytic and the non-saccharolytic biotype.

\section{Animal pathogenicity}

Of the 65 strains tested for pathogenicity, 19 killed one or two mice within 7 days. Details of these pathogenic strains are given in table IV. Postmortem examination of the mice killed by these strains showed hyperaemia of the peritoneum with some exudate formation but no involvement of other organs. The strain isolated from a normal ear was not tested for pathogenicity.

\section{Clinical findings}

Fifty-seven strains were isolated over a period of 26 months from 55 patients whose ages ranged from 7 months to 75 years. In 12 instances the isolations were made in pure culture, but usually the organisms were found in mixed growths, together with such potential pathogens as Streptococcus pyogenes, Staphylococcus aureus and Haemophilus influenzae, or with commensals of the skin or respiratory tract, or with faecal organisms. Table $\mathrm{V}$ shows, in relation to the three clinical diagnoses of acute otitis media, otitis externa and chronic otitis media, isolations of Acinetobacter that consisted either of pure cultures or cultures mixed only with normal skin flora; the responses obtained to antibacterial therapy are also shown.

Two patients with acute otitis media from whom Acinetobacter was isolated together with, respectively, penicillin-sensitive Staph. aureus and tetracycline-resistant Strept. pyogenes, are of special interest. The first patient failed to respond to systemic penicillin, but when tetracycline was substituted the ear condition cleared within 2 weeks. The second patient failed to respond to systemic tetracycline, but the substitution of systemic penicillin together with local neomycin and polymyxin cleared the ear in 10 days. 
TABLE IV

Results of pathogenicity tests

\begin{tabular}{l|cccc}
\hline Organism & $\begin{array}{c}\text { Total number } \\
\text { of strains } \\
\text { examined }\end{array}$ & $\begin{array}{c}\text { Number that } \\
\text { killed 1-2 mice } \\
\text { in 1-7 days }\end{array}$ & $\begin{array}{c}\text { Number of } \\
\text { pathogenic strains } \\
\text { recovered from } \\
\text { peritoneum }\end{array}$ & $\begin{array}{c}\text { Number of } \\
\text { pathogenic strains } \\
\text { showing capsular } \\
\text { staining }\end{array}$ \\
\hline $\begin{array}{c}\text { A. anitratus } \\
\text { (clinical isolates) }\end{array}$ & 32 & 13 & 8 & 0 \\
$\begin{array}{c}\text { Anitratus } \\
\text { (type strains) }\end{array}$ & 4 & 3 & 3 & 0 \\
$\begin{array}{c}\text { A.lwoffi } \\
\text { (clinical isolates) }\end{array}$ & 21 & 3 & 3 & 1 \\
$\begin{array}{c}\text {.lwoffi } \\
\text { (type strains) }\end{array}$ & 4 & 0 & 0 & 0 \\
$\begin{array}{c}\text { Moraxella } \\
\text { Achromobacter }\end{array}$ & 3 & 0 & 0 & 0 \\
\hline
\end{tabular}

In the patients with otitis externa and chronic otitis media from whom mixed cultures were obtained that usually included Staph. aureus, with or without Esch. coli, Proteus spp., Pseudomonas spp., Strept. pyogenes and Strept. faecalis, the clinical courses varied a great deal. Some ears were clear in a week or so whereas others continued to give trouble many months later; most received some form of antibiotic treatment.

One strain of $A$. lwoffii was isolated from a normal ear in a mixed culture with Staph. epidermidis and diphtheroid organisms.

\section{Discussion}

Most of the organisms isolated in this study clearly belong to the genus now usually called Acinetobacter. Eight, however, were atypical-three gave a positive oxidase reaction, one reduced nitrate, two were VP positive, one was MR and VP positive and one was motile.

Two main biotypes have been described for this group-those that produce acid from glucose and a few other carbohydrates and those that do not. The former have been given the specific name Acinetobacter anitratus and the nonsaccharolytic strains are called Acinetobacter lwoffii (Cowan and Steel, 1974); the present strains can be grouped in this way. Such properties as the ability to liquefy gelatin, to utilise citrate, and to produce urease, have been reported as being more variable and were found in this study to be shared between members of both main biotypes.

Another property found in both biotypes was soap tolerance, originally described by Billing (1955) for strains of "Achromobacter anitratum". Of the 17 strains with this property in the present series, six fell into the lwoffi group, and there was no relation between soap tolerance and the ability to liquefy gelatin. Lecithinase production was likewise variable.

The results of the serological studies are less definite. Four main patterns 
TABLE V

Isolations in relation to clinical diagnosis and response to antibacterial treatment

\begin{tabular}{|c|c|c|c|c|c|}
\hline \multirow{2}{*}{$\begin{array}{l}\text { Number of } \\
\text { patients with } \\
\text { the indicated } \\
\text { diagnosis }\end{array}$} & \multirow{2}{*}{$\begin{array}{l}\text { Strains isolated } \\
\text { in pure culture } \\
\text { or with normal } \\
\text { skin flora only }\end{array}$} & \multicolumn{2}{|c|}{ Antibacterial therapy } & \multirow{2}{*}{$\begin{array}{c}\text { Duration } \\
\text { of } \\
\text { therapy }\end{array}$} & \multirow{2}{*}{ Response } \\
\hline & & Local & Systemic & & \\
\hline \multirow{3}{*}{$\begin{array}{l}\text { Acute otitis } \\
\text { media, 13 }\end{array}$} & $\begin{array}{l}\text { A. lwoffii } \\
\text { A. lwoffii }\end{array}$ & $\cdots$ & $\cdots$ & $\cdots$ & $\ldots$ \\
\hline & A. anitratus & $\begin{array}{l}\text { None } \\
\text { Polymyxin }\end{array}$ & $\begin{array}{l}\text { Penicillin } \\
\text { Tetracycline }\end{array}$ & $\begin{array}{l}1 \mathrm{wk} \\
1 \mathrm{wk}\end{array}$ & $\begin{array}{l}\text { None } \\
\text { Good }\end{array}$ \\
\hline & $\begin{array}{l}\text { A. lwoffii* } \\
\text { A. anitratus } \\
\text { with skin flora }\end{array}$ & $\begin{array}{l}\text { Chloramphenicol } \\
\text { None }\end{array}$ & $\begin{array}{l}\text { Tetracycline } \\
\text { None }\end{array}$ & $1 \mathrm{wk}$ & $\begin{array}{l}\text { Good } \\
\text { Good }\end{array}$ \\
\hline \multirow{7}{*}{$\begin{array}{l}\text { Chronic otitis } \\
\text { media, } 34\end{array}$} & $\begin{array}{l}\text { A. anitratus } \dagger \\
\text { A. lwoffi } \\
\text { A. anitratus } \\
\text { A. lwoffii } \ddagger \\
\text { A. anitratus }\end{array}$ & $\begin{array}{l}\text { None } \\
\text { Framycetin } \\
\text { None } \\
\text { Polymyxin } \\
\text { and neomycin }\end{array}$ & $\begin{array}{l}\text { None } \\
\text { None } \\
\text { None } \\
\text { None }\end{array}$ & $\begin{array}{l}1 \mathrm{wk} \\
1 \mathrm{w} \\
1 \mathrm{k}\end{array}$ & $\begin{array}{l}\text { Good } \\
\text { Good } \\
\text { Good } \\
\text { Good }\end{array}$ \\
\hline & Moraxella & $\begin{array}{l}\text { Polymyxin } \\
\text { and neomycin }\end{array}$ & None & $\begin{array}{c}2 \text { months } \\
\text { inter- } \\
\text { mittent }\end{array}$ & $\begin{array}{l}\text { Poor until opera- } \\
\text { tive treatment } \\
\text { performed }\end{array}$ \\
\hline & Moraxella & Polymyxin and & None & $1 \mathrm{wk}$ & Good \\
\hline & $\begin{array}{c}\text { Achromobacter* } \\
\text { with skin flora }\end{array}$ & Neomycin & Penicillin & $1 \mathrm{wk}$ & Good \\
\hline & $\begin{array}{l}\text { A. lwoffii } \\
\text { with skin flora }\end{array}$ & Neomycin & Penicillin & $1 \mathrm{wk}$ & $\begin{array}{l}\text { Poor until opera- } \\
\text { tive treatment } \\
\text { performed }\end{array}$ \\
\hline & $\begin{array}{l}\text { A. lwoffii } \\
\text { with skin flora }\end{array}$ & None & None & $\cdots$ & $\begin{array}{l}\text { Moderate until } \\
\text { operative treat- } \\
\text { ment performed }\end{array}$ \\
\hline & $\begin{array}{l}\text { A. lwoffii } \neq \\
\text { with skin flora }\end{array}$ & None & None & $\cdots$ & Good \\
\hline Otitis externa, 8 & A. Iwoffii $\dagger$ & $\cdots$ & $\ldots$ & $\cdots$ & $\ldots$ \\
\hline
\end{tabular}

* = Strains resistant to the antibiotics given, $\dagger=$ no clinical details obtained, $\ddagger=$ isolated from bone chips obtained at mastoidectomy, $\ldots=$ no observations possible.

of agglutination were found, but many strains gave individual patterns and some did not react at all with the antisera; this suggests that there is a diversity of antigenic types. A degree of antigenic similarity was found between members of the two main biotypes, but no definite relationship could be demonstrated between the type strains and the clinical isolates. It is evident from the literature that a considerable number of serological types exist that do not correspond with the biochemical groupings, and that some antigens are shared with organisms of otherwise unrelated groups such as Klebsiella (Aiken, Ward and King, 1956; Daly, Postic and Kass, 1962; Lothe and Griffin, 1965), and Chlamydia (Matthiesen and Volkert, 1957). Further studies on the antigenic relationships of Acinetobacter are required.

Most authors have reported Acinetobacter to be resistant to penicillin, and all but three of the clinical isolates studied here were found to be so. These 
three penicillin-sensitive strains were also oxidase positive, and this suggests that they should be considered as belonging to the genus Moraxella (Wilson and Miles, 1974). Surprisingly, one type strain of $A$. lwoffii was penicillin sensitive. Most of the strains were sensitive to erythromycin and ampicillin, but they varied in their reactions to tetracycline and streptomycin; a high proportion was chloramphenicol resistant, a property to which Lothe and Griffin (1965) drew particular attention.

Most of the clinical isolates were non-pathogenic for mice; the majority of those that were pathogenic to mice belonged to the anitratus group, and a similar relationship was also noted for the type strains. No clear-cut pattern of pathogenicity is described in the literature.

It is difficult to assess the pathogenicity of the present strains for the human ear. That pure cultures were relatively uncommon suggests pathogenicity of a low order, and indeed many strains were isolated together with an organism such as Staph. aureus or Proteus that might be expected to play a more prominent part in any inflammatroy process; other workers have also noted this association (Brooke, 1951; Scott and Mahoney, 1953).

Further evidence of lack of pathogenicity is provided by the two patients in this series who underwent mastoidectomy. In both instances Acinetobacter was isolated from the bone chips obtained at operation, suggesting fairly deep penetration of the organisms, yet neither patient required special post-operative treatment or antibiotic therapy. It may, however, be of some significance that these strains were both of the lwoffii group.

In contrast, evidence pointing to some measure of pathogenicity was obtained from the patients with acute otitis media. Pure cultures of Acinetobacter were obtained from four of these, and at least one required appropriate antibiotic treatment before the ear was satisfactorily healed; the infecting strain belonged to the anitratus group and was pathogenic for mice. In a second patient with acute otitis media a penicillin-sensitive Staph. aureus was the only other organism isolated. The ear did not respond to treatment until tetracycline, to which the acinetobacter was sensitive, was substituted for the penicillin given initially. This strain was also a member of the anitratus group but was not pathogenic for mice.

On balance the evidence points to a degree of pathogenicity for the ear that varies with individual strains, with a suggestion that saccharolytic strains are more likely to be pathogenic. In most instances, however, their presence would seem to indicate little more than their opportunistic potential.

There is evidence that Acinetobacter organisms may form part of the normal skin flora (Taplin, Rebell and Zaias, 1963; Greer, Mikhail and Livingood, 1965; Donald, 1966) and the isolation of one of the present strains from a normal external ear supports this concept. Garrison (1963) has suggested that the frequent occurrence of this group of organisms in soil may account for their isolation from the respiratory tract; it is perhaps surprising that they are apparently so seldom isolated from such sites as the ear.

A few of the present strains were not entirely typical. One of these reduced nitrate, but this property no longer excludes it from the genus Acinetobacter 
(Jyssum and Joner, 1965); nor does exclusion seem justified for the three strains that gave positive MR or VP reactions.

The three non-saccharolytic oxidase-positive strains fit best into the genus Moraxella. Thornley (1967) found a close relationship between the oxidasepositive, penicillin-sensitive strains and typical oxidase-negative, penicillinresistant Acinetobacter strains, but evidence from other studies is considered sufficient to justify their generic separation (Baumann, Doudoroff and Stanier, 1968; Johnson, Anderson and Ordal, 1970).

\section{SUMMARY}

Fifty-seven strains of acinetobacter-like organisms were isolated over a period of 26 months from the ears of 55 patients with acute or chronic otitis media, or otitis externa, and one strain was isolated in a survey of 50 normal ears. After comparison with eight reference strains, 32 of the isolates were identified as Acinetobacter anitratus, 22 as Acinetobacter lwoffi, three as Moraxella spp. and one as Achromobacter sp.

Analysis of the clinical findings suggests that although most of these organisms played little part in the disease process, a few strains were probably pathogenic in this situation.

I wish to thank the surgeons at the Royal National Throat, Nose and Ear Hospital, London, for providing the material from their patients and permitting access to their case notes; Professors A. C. Cunliffe and I. Friedmann for their helpful advice; Mrs E. Taylor and Mr I. Saxton for their technical assistance; and the students and staff at King's College Hospital Medical School, London, who permitted me to swab their ears.

\section{REFERENCES}

AIKen, M. A., WARD, M. K. AND KING, E. O. 1956. A study of a group of Gram-negative bacteria resembling the tribe Mimeae (De Bord). Publ. Hlth Lab., 14, 126.

Baumann, P., Doudoroff, M. and Stanier, R. Y. 1968. A study of the Moraxella group. II. Oxidative-negative species (Genus Acinetobacter). J. Bact., 95, 1520.

Berenbaum, M. C. 1955. The staining of bacterial capsules and slime with ferric compounds. J. clin. path., 8, 343.

Billing, E. 1955. Studies on a soap tolerant organism; a new variety of Bacterium anitratum. J. gen. Microbiol., 13, 252.

Brodie, J. AND Henderson, A. (1964). Further observations on Mima polymorpha and Achromobacter (Bacterium) anitratum. J. clin. Path., 17, 513.

Brooke, M. S. 1951. The occurrence of B5W (B. anitratum) strains in Denmark. Acta path. microbiol. scand., $28,338$.

Cook, G. T. 1950. A plate test for nitrate reduction. J. clin. Path., 3, 359.

CowAN, S. T. AND SteEL, K. J. 1974. Manual for the identification of medical bacteria, 2nd ed., London.

Daly, A. K., Postic, B. AND Kass, E. H. 1962. Infections due to organisms of the genus Herellea, B5W and B. anitratum. Archs intern. Med., 110, 580.

DE BoRD, G. G. 1939. Organisms invalidating the diagnosis of gonorrhoea by the smear method. J. Bact., 38, 119.

De Torregrosa, M. V. AND Ortiz, A. 1961. Severe infections in children due to rare gram-negative bacilli (Mima polymorpha and Bacillus anitratum). J. Pediat., 59, 35.

Donald, W. D. 1966. Studies on Mimeae organisms as related to infants and children. Pediatrics, Springfield, 37, 756. 
GARRISON, R. G. 1963. The occurrence of Bacterium anitratum in secretions of pulmonary origin. Am. J. clin. Path., 40, 260.

Greer, J. E., Mikhail, G. R. AND Livingood, C. S. 1965. Incidence of Mima and Herellea on human skin. Bact. Proc., p. 49.

Johnson, J. L., ANDERson, R. S. AND Ordal, E. J. 1970. Nucleic acid homologies among oxidase-negative Moraxella species. J. Bact., 101, 568.

JYSSUM, K. AND JONER, P. E. 1965. Regulation of the nitrogen assimilation from nitrate and nitrite in Bacterium anitratum (B5W). Acta path. microbiol. scand., 64, 387.

Lothe, F. AND GRIFFIN, E. 1965. Bacterium anitratum and Mima polymorpha infection in Uganda. J. clin. Path., 18, 301.

Lutz, A., Grootten, O., Velu, H. ANd Velu, M. 1956. Role pathogène et fréquence des bactéries du type Bacterium anitratum. Annls Inst. Pasteur, Paris, 91, 413.

Matthiesen, M. AND VolkeRT, M. 1957. The antigenic relationship between ornithosis virus and Bacterium anitratum. Acta path. microbiol. scand., 41, 135.

Reynolds, R. C. AND Cluff, L. E. 1963. Infection of man with Mimeae. Ann. intern. Med., 58, 759.

Scott, E. G. AND Mahoney, B. A. 1953. The occurrence of members of the tribe Mimeae in human infections. Delaware State med. J., 25, 22.

Shmilowiz, M., Avissar, R. AND EPhrati, Z. 1968. Infections due to Herellea vaginicola and Mima polymorpha. Harefuah, 75, 297.

TAPlin, D., Rebell, G. AND Zaias, N. 1963. The human skin as a source of Mima-Herellea infections. J. Am. med. Ass., 186, 952.

Thornley, M. J. 1967. A taxonomic study of Acinetobacter and related genera. J. gen. Microbiol., 49, 211.

Wilson, G. S. AND Miles, A. A. 1974. Topley and Wilson's Principles of bacteriology, virology and immunity, 6th ed., London, p. 704.

WRIGHT, I. 1970. The bacteriology of ear, nose and throat diseases. J. Lar. Otol., 84, 283. 